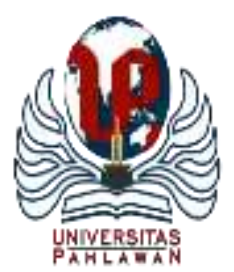

\title{
JURNALBASICEDU
}

Volume 5 Nomor 6 Tahun 2021 Halaman 5342 - 5351

Research \&Learningin Elementary Education https://jbasic.org/index.php/basicedu

\section{Nilai-nilai Karakter pada Permainan Tradisional Hadang di Sekolah Dasar}

\author{
Feby Elra Perdima ${ }^{1 凶}$, Muhammad Kristiawan ${ }^{2}$ \\ Universitas Dehasen Bengkulu, Indonesia ${ }^{1}$ \\ Universitas Bengkulu, Indonesia ${ }^{2}$ \\ E-mail: Feby.elra@unived.ac.id ${ }^{1}$, muhammadkristiawan@unib.ac.id ${ }^{2}$
}

\begin{abstract}
Abstrak
Teknologi yang mulai menjamur di masyarakat dikala ini, permainan tradisonal mulai tidak terjamah lagi oleh generasi muda. Tujuan penelitian ini untuk melihat nilai nilai karakter yang terkandung dalam permainan hadang. Metode penelitian ini adalah metode kuantitatif, sampel diambil mengunakan teknik sampling jenuh dengan sampel sebanyak 28 siswa. Pengambilan data melakukan observasi pada permainan hadang. Hasil penelitian: (1) Nilai karakter religius dalam permainan hadang dengan skor 60 (72.29\%) dalam katagori selalu memiliki nilai karakter religius, 2) Nilai karakter displin: skor 88 (78.575) katagori selalu memiliki nilai karakter displin, 3) Nilai karakter jujur skor 35 (62.50\%) katagori selalu berkarakter jujur, 4) Nilai karakter kerja keras: skor 87 (78.38\%) katagori selalu berkerja keras, 5) Nilai karakter tangung Jawab skor 33 (58.93\%) katagori selalu bertanggung jawab, skor 15 (26.79\%). Jadi siswa sudah menerapkan nilai-nilai karakter dalam permainan hadang
\end{abstract}

Kata Kunci: Nilai karakter; permainan tradisonal.

\begin{abstract}
Technology that is spreading in society at this time, traditional games are starting to be unknown by the younger generation. This study aims to observe the character values contained in Hadang game. This research method is quantitative method, the sample is taken using a saturated sampling technique with a sample of 28 students. Data retrieval conducted observations on the game of Hadang. The results of the study: (1) The value of religious characters can be explained: a score of 60 (72.29\%) in the category always has a religious character value. 2) Discipline Character Value: A score of $88(78,575)$ in a category always has a disciplinary character value. 3) Honest Character Value a score of 35 (62.50\%) category always has honest character. 4) Value of hard work character: a score of 87 (78.38\%) in the category of always working hard. 5) Responsibility Character Value, a score of 33 (58.93\%) always responsible category, a score of 15 (26.79\%) often responsible category, therefore students who apply character values in Hadang Game
\end{abstract}

Keywords: Character Value; Hadang Traditional Game

Copyright (c) 2021 Feby Elra Perdima, Muhammad Kristiawan

$\triangle$ Corresponding author :

Email : Feby.elra@unived.ac.id

DOI : https://doi.org/10.31004/basicedu.v5i6.1640 
5343 Nilai-nilai Karakter pada Permainan Tradisional Hadang di Sekolah Dasar - Feby Elra Perdima, Muhammad Kristiawan

DOI: https://doi.org/10.31004/basicedu.v5i6.1640

\section{PENDAHULUAN}

Di lingkungan sekolah memiliki suatu program mata pelajaran Pendidikan Jasmani Olahraga Kesehatan. Menurut (Kementerian Olahraga, 2005) Olahraga pendidikan adalah pendidikan jasmani dan olahraga yang dilaksanakan sebagai bagian proses pendidikan yang teratur dan berkelanjutan untuk memperoleh pengetahuan, kepribadian, keterampilan, kesehatan, dan kebugaran jasmani. Kandungan dalam mata pelajaran pendidikan jasmnai olahraga dan olahraga adalah pendidikan karakter yang terkandung dalam penilaian afektif siswa. Karakter mulia mencakup pengetahuan tentang kebaikan (akhlak behavior) kemudian menibulkan komitmen ataum hasrat terhadap kebaikan (moral feeling) dan akhirnya benar- benar melakukan kebaikan (akhlak behavior). Dengan kata lain, kepribadian merujuk pada serangkaian wawasan (cognitivies), tindakan(attituded), dan motivasi (motivation), dan perilaku (behavior), serta keahlian(skills) (Amirudin, 2019)

Teknologi yang mulai menjamur di masyarakat dikala ini, permainan konvensional/tradisonal mulai tidak terjamah lagi oleh anak- anak kecil dilingkungan kita. Tipe permainan rakyat (permainan anak) bisa meningkatkan kemampuan kecerdasan jamak, seperti kecerdasan linguistik, intelek akal sehat, intelek visual- spasial, intelek kinestetik tubuh, intelek musik, intelek interpersonal (Sonjaya et al., 2021). Pada hal banyak manfaat dari permainan tradisonal guna memberikan efek positif dalam perbaikan motorik, salah satunya tingkatkan kekebalan badan siswa yang berupa gerak lokomotor (berlari, berjalan, meloncat, melompat), nonlokomotor (mendarat, berbelok, berputar), manipulatif (memukul, menghentikan, menepuk) dengan sangat efisien (Ewan Irawan et al., 2021). Senada dengan pendapat di atas permainan tradisonal mengarahkan pentingnya suatu cara serta menyisipkan nilai- nilai kebaikan pula memiliki kearifan lokal yang amat mendidik serta memancing rasa semangat kebangsaan anak. Tidak hanya itu walaupun permainan tradisional ialah permainan yang simpel, tetapi bisa memberikan manfaat yang luar biasa seperti melatih anak dalam kehidupan sosial paling utama dengan teman sebayanya, melatih ketangkasan, serta meningkatkan motorik anak (Maulana \& Riyadi, 2021). Hasil penelitian Kurniati dalam (Nur, 2013) menunjukkan bahwa permainan anak tradi- sional dapat mestimulasi anak dalam mengembangkan kerja sama, membantu anak menyesuaikan diri, saling berinteraksi secara positif, dapat mengkondisikan anak dalam mengontrol diri, mengembangkan sikap empati terhadap teman, menaati aturan, serta menghargai orang lain.

(Nanda \& Sugito, 2015) memberikan penjelaskan manfaat untuk perkembangan pertumbuhan anak. Permainan tradisional mempunyai hubungan yang erat dengan perkembangan intelektual, sosial, serta karakter anak. Permainan tradisional juga mampu mengasah aspek pengendalian diri, yaitu kemampuan anak untuk menunda kepuasan, bisa bersabar, tidak mudah tersinggung, rasa percaya diri, sikap pantang menyerah, dan sebagainya. Kajian penelitian (Andriani, 2012) menyebutkan bahwa "One way to increase the potential of children at an early age is to play. Because the slogan in early childhood education is "learning while playing, playing while learning." This is the basis, that the play is one way to explore the potential of children. One tool that can be used to play in early childhood education, this is by using the traditional game, because the game tardisional will help shape the character of a child from an early age".

Dengan demikian, dapat dipahami bahwa permainan tradisional dapat memberikan dampak yang sangat baik dalam membantu mengembangkan keterampilan emosi dan sosial anak. Hasil penelitian Misbach dalam (Maulana \& Riyadi, 2021) membuktikan kalau permainan tradisional bisa memotivasi bermacam pandangan perkembangan anak yang bisa mencakup keadaan sebagai berikut. Aspek motorik dengan melatih daya tahan, daya lentur, sensorimotorik, motorik agresif, serta motorik lembut. Pandangan kognitif dengan meningkatkan imaginasi, daya cipta, dilema solving, strategi, keahlian antisipatif, serta pemahaman kontekstual. Pandangan bahasa berbentuk uraian konsep-konsep angka. Pandangan nilai- nilai 
5344 Nilai-nilai Karakter pada Permainan Tradisional Hadang di Sekolah Dasar - Feby Elra Perdima, Muhammad Kristiawan

DOI: https://doi.org/10.31004/basicedu.v5i6.1640

atau akhlak dengan memfa- silitasi anak buat bisa mendalami nilai- nilai akhlak yang diwariskan dari angkatan terdahulu pada angkatan selanutnya.

(Safari \& Safari, 2010) menyatakan bahwa permainan hadang dapat membentuk karakter siswa yakni unsur kooperatif yang meliputi kerja sama tim, strategi bermain, dan koordinasi antar anggota tim. Selain itu, permainan hadang banyak memiliki nilai positif yang di antaranya adalah kebersamaan dalam bentuk kerja sama yang kompak antara satu penjaga dengan penjaga lain agar lawan tidak lolos. Di sisi lain, pada regu yang sedang memainkan permainan ini dituntut kecepatan untuk berpikir saat akan melewati pintu-pintu yang dihalangi bisa lolos dari penjagaan senada dengan itu.

Penelitian-penelitian mengenai pendidikan karkter telah banyak dilakukan oleh para pakar maupun praktisi pendidikan. Namun, selama ini yang diangkat adalah penerapan nilai-nilai karakter melalui olahraga permainan tradisional hanya dari beberapa butir nilai. Tetapi, penulis merasa masih perlu mengkaji lebih dalam mengenai penerapan nilai-nilai karakter secara berkelanjutan. Penulis berusaha untuk mengungkapkan bahwa dalam olahraga permainan tradisional terdapat nilai-nilai karakter yang harus diketahui dan diterapkan siswa kapanpun dan dimanapun mereka melakukan kegiatan olahraga. Belum ada penelitian yang mengangkat penguatan nilai-nilai karakter dalam permainan tradisional di Sekolah Dasar 1 Muara Aman Kabupaten Lebong, membuat penulis merasa perlu untuk meneliti ini

\section{METODE PENELITIAN}

Penelitian ini bertujuan untuk membuat deksripsi, gambaran dan tulisan secara sistematis, faktual dan akurat (Ajat Rukajat, 2018). Penelitian ini nantinya, akan mendeskripsikan temuan-temuan di lapangan berupa nilai-nilai karakter yang muncul pada saat melakukan aktivitas permainan tradisional hadang. Adapun populasi penelitian ini adalah semua siswa kelas VI 1 Sekolah Dasar 1 Muara Aman yang berjumlah 28 orang. Sedangkan sampel dalam penelitian berjumlah 28 orang dengan penarikan sampel mengunakan teknik sampling jenuh. Sampling jenuh adalah penarikan sampel jika semua anggota populasi digunakan sebagain sampel, jika populasi kurang dari 30 orang (Siyoto \& Sodik, 2015). Menurut (Huda \& Prasetyo, 2016) Instrumen yang digunakan adalah observasi dan survei nilai nilai karakter jujur, religious, disiplin/sportifitas, pantang menyerah/kerja keras. Tanggung jawab/kekompakan tim. Ada pun indikator penilaiannya sebagai berikut :

\begin{tabular}{|c|c|c|c|}
\hline No & Karakter & Indikator & $\begin{array}{llll} & & & \\
4 & 3 & 2 & 1\end{array}$ \\
\hline 1 & 1. Religius & $\begin{array}{l}\text { a. Berdoa sebelum bermain } \\
\text { b. Berdoa setelah bermain } \\
\text { c. Mengucapkan syukur saat } \\
\text { menang }\end{array}$ & \\
\hline & 2. Disiplin & $\begin{array}{l}\text { a. Berkumpul di lapangan tepat } \\
\text { waktu } \\
\text { b. Menggunakan seragam } \\
\text { olahraga lengkap } \\
\text { c. Berbaris dengan tertib } \\
\text { d. Mematuhi aturan permainan }\end{array}$ & \\
\hline & 3. Jujur & $\begin{array}{ll}\text { a. Bermain dengan jujur } & \\
\text { b. } & \text { Mengakui kesalahan yang } \\
\text { dilakukan }\end{array}$ & \\
\hline & 4. Kerja Keras & $\begin{array}{ll}\text { a. } & \text { Berusaha memenangkan } \\
\text { permainan } & \\
\text { b. } & \text { Percaya diri saat bermain }\end{array}$ & \\
\hline
\end{tabular}


5345 Nilai-nilai Karakter pada Permainan Tradisional Hadang di Sekolah Dasar - Feby Elra Perdima, Muhammad Kristiawan

DOI: https://doi.org/10.31004/basicedu.v5i6.1640

\begin{tabular}{|c|c|c|c|c|}
\hline \multirow[t]{2}{*}{ No } & Karakter & Indikator & $\begin{array}{llll}4 & 32 & \end{array}$ & Ket \\
\hline & & $\begin{array}{ll}\text { c. } & \text { Bersungguh-sungguh dalam } \\
\text { bermain } \\
\text { d. Tidak mudah putus asa dalam } \\
\text { bermain }\end{array}$ & & \\
\hline & $\begin{array}{l}\text { 5. } \begin{array}{l}\text { Tanggung } \\
\text { Jawab }\end{array} \\
\text { Jaw }\end{array}$ & $\begin{array}{l}\text { a. Siswa menjalankan tugasnya } \\
\text { dengan baik } \\
\text { b. Bisa mempertahankan timnya } \\
\text { untuk menang }\end{array}$ & & \\
\hline
\end{tabular}

Penilaian ini dilakukan pada saat siswa melakukan permainan hadang yang sedang berlangsung. Pada saat permainan berlansung maka akan nampak beberapa siswa akan terlihat nilai nilai karakter yang munculdan penerapkan nilai-nilai karakter saat bermain hadang. Adapun teknik analisis yang dilakukan, yaitu: 1) Penulis mengklasifikasikan nilai-nilai karakter yang terdapat dalam pembelajaran olahraga permainan tradisional pada kegiatan pembuka, inti dan penutup. 2) Setelah melakukan klasifikasi, selanjutnya penulis akan mendeskripsikan setiap bentuk nilai-nilai karakter yang terdapat dalam pembelajaran olahraga permainan tradisional. 3) Langkah berikutnya setelah mendeskripsikan data yaitu menganalisis data. Data yang dianalisis adalah data-data berupa bentuk nilai-nilai yang terdapat dalam permainan trasisional. Satu persatu di analisis dan ditemukan nilai-nilai karakter yang sudah diterapkan dan yang belum. 4) Langkah terakhir dalam menganalisis data yaitu mengambil kesimpulan dari rumusan masalah dan tujuan yang telah terjawab. Kesimpulan yang dibuat berupa kesimpulan secara umum mengenai nilai-nilai karakter dalam pembelajaran olahraga permainan tradisional.

\section{HASIL DAN PEMBAHASAN}

Hasil dan pembahasan berisi hasil-hasil temuan penelitian dan pembahasannya permainan tradisional yang bersifat edukatif memiliki nilai-nilai karakter yang baik, maka akan sangat berperan besar dalam kehidupan anak-anak sehari-hari. Permainan tradisional banyak sekali nilai-nilai karakter yang ditanamkan saat memainkannya sebab anak dapat belajar bersosialisasi dengan lingkungannya, berinteraksi secara langsung dengan teman-temannya. permainan tradisional sebagai produk lokal yang tersebar, terutama di masyarakat lokal dimainkan oleh anak-anak di luar rumah sehingga akan terjadi banyak interaksi sosial. Proses pembelajaran melalui permainan dalam mata pelajaran pendidikan jasmani di sekolah membantu siswa membiasakan diri untuk selalu menunjukkan perilaku-perilaku yang baik. Adapun Nilai-nilai karakter yang terlihat saat siswa kelas VI Sekolah Dasar 1 Muara Aman Kabupaten Lebong yang berjumlah 28 orang bermain permainan tradisional Hadang pada bulan Agustus tahun 2020 sebagai berikut:

\section{Nilai Karakter Religius}

Karakter religius ialah tindakan ataupun sikap yang dekat dengan keadaan kebatinan, taat melakukan anutan agama yang dianutnya, toleran terhadap pelaksanaan ibadah agama lain, dan hidup rukun dengan pemeluk agama lain. (Hariandi \& Irawan, 2016). Selain itu pendapat (Khotimah, 2016) bahwa kepribadian religius berperan buat membuat pemahaman manusia mengenai keberadaan Tuhan dan hubungannya dengan pencipta. Adapun nilai karakter religius yang di teliti adalah 1) Berdoa sebelum bertanding, $75 \%$ siswa selalu berdoa sebelum bertanding, 2) Berdoa sesudah bertanding dan 3) bersyukur kala menang. Maka hasil penelitian mengenai nilai-nilai katakter religius dapat di lihat pada tabel di bawah ini sebagai berikut : 
Tabel 1. Nilai Karakter Religius

\begin{tabular}{lccccc}
\hline No & Aspek Penilaian & Selalu & iering & $\begin{array}{c}\text { Kadang } \\
\text { Kadang }\end{array}$ & Tidak Pernah \\
\hline 1 & Berdoa sebelum bertanding & 21 & 7 & 0 & 0 \\
\hline 2 & Berdoa sesudah bertanding & 20 & 8 & 0 & 0 \\
\hline 3 & Bersyukur kala menang & 19 & 5 & 3 & 0 \\
\hline & Jumlah & $\mathbf{6 0}$ & $\mathbf{2 0}$ & $\mathbf{3}$ & $\mathbf{0}$ \\
\hline
\end{tabular}

Berdasarkan tabel 1. Mengenai nilai karakter religious maka dapat di jelaskan: skor 60 (72.29\%) dalam katagori selalu memilki nilai karakter religious ,skor 20 (24.10\%) dalam katagori sering memilki karakter religious, skor 3 (3.61\%) dalam katagori kadang-kadang memilki nilai karakter religius, dan $0(0 \%)$ dalam katagori tidak pernah memilki nilai karakter religius. Serta dapat di jelaskan juga hasil penelitian nilai katakter religious dengan format diagram batang di bawah ini :

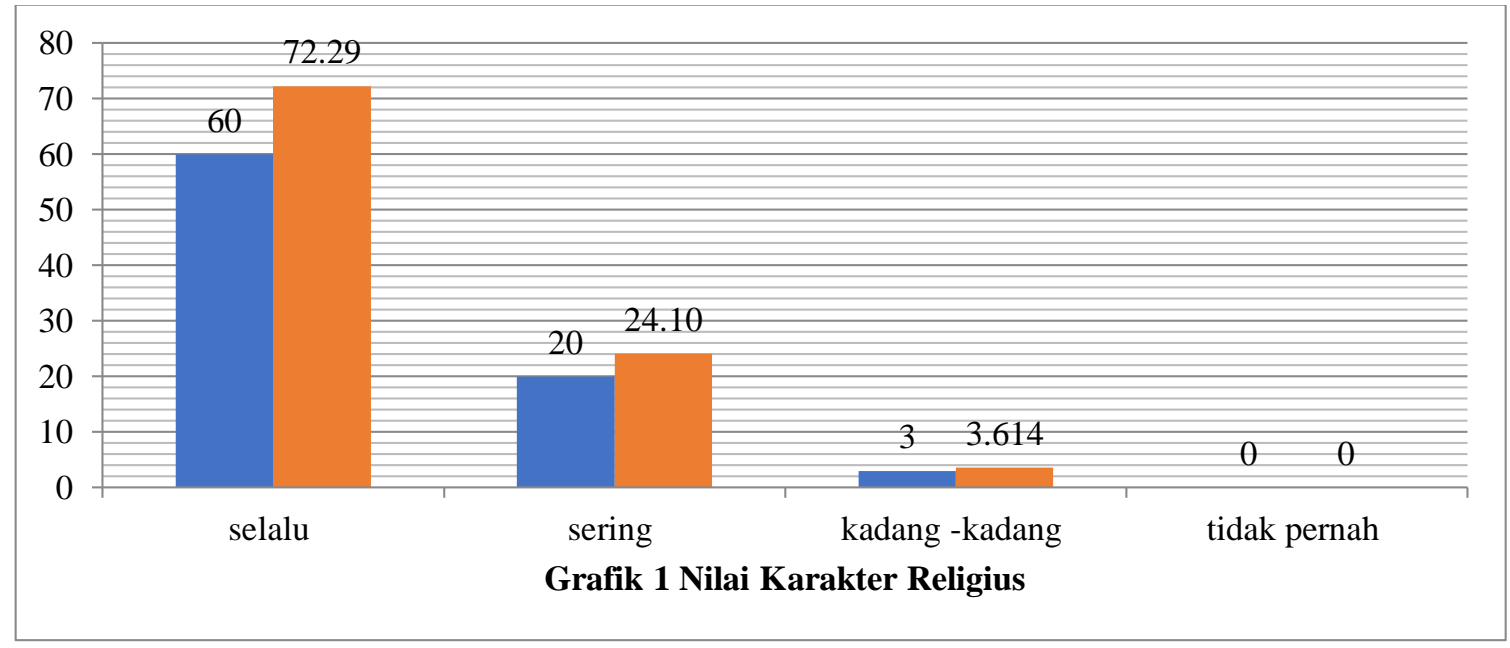

\section{Nilai Karakter Displin}

Nilai karakter displin adalah akan mendorong dihasilkannya sesuatu tepat pada waktunya (Atika, 2018), senaa dengan itu kajian dari (Sobri et al., 2019) karakter disiplin ditunjukkan saat mereka datang tepat waktu berkumpul di lapangan olahraga. Selain itu, mereka menggunakan seragam sesuai dengan aturan yang telah ditetapkan sekolah. Karakter disiplin juga terlihat dari cara siswa berbaris saat memulai permainan. Mereka berbaris dengan tertib saat menunggu giliran pembagian kelompok, maupun saat permainan sudah usai. Karakter disiplin pada saat bermain hadang ditunjukkan siswa saat menjadi penjaga pada permainan, siswa harus menjaga siswa lain yang tidak jaga agar tidak lolos melewati semua penjaga sampai pada kotak terakhir. Apabila siswa yang jaga tidak disiplin, maka dengan mudah siswa yang tidak jaga melewatinya sebab pergerakan siswa dibatasi oleh garis-garis area permainan. Nilai Kedisiplinan siswa dalam permainan hadang dapat di lihat di tabel 2.

Tabel 2. Nilai Karakter Disiplin

\begin{tabular}{cccccc}
\hline No & Aspek Penilaian & Selalu & sering & $\begin{array}{c}\text { kadang } \\
\text { kadang }\end{array}$ & idak pernah \\
\hline 1 & siswa berkumpuldi lapangan & 25 & 3 & 0 & 0 \\
\hline 2 & seragam lengkap & 26 & 1 & 1 & 0 \\
\hline 3 & tertib berbaris & 21 & 7 & 0 & 0 \\
\hline 4 & Mematuhi Aturan Permainan & 16 & 10 & 2 & 0 \\
\hline & jumlah & 88 & 21 & 3 & 0 \\
\hline
\end{tabular}


5347 Nilai-nilai Karakter pada Permainan Tradisional Hadang di Sekolah Dasar - Feby Elra Perdima, Muhammad Kristiawan

DOI: https://doi.org/10.31004/basicedu.v5i6.1640

Berdasarkan tabel 2. Mengenai nilai karakter disiplin maka dapat di jelaskan : Skor 88 (78.575) dalam katagori selalu memiliki karakter disiplin, Skor 21 (18.75) dalam katagori sering memiliki karakter disiplin, Skor 3 (1.79\%) dalam katagori kadang-kadang memiliki karakter disiplin. Serta dapat di jelaskan juga hasil penelitian nilai katakter disiplin dengan format diagram batang di bawah ini :

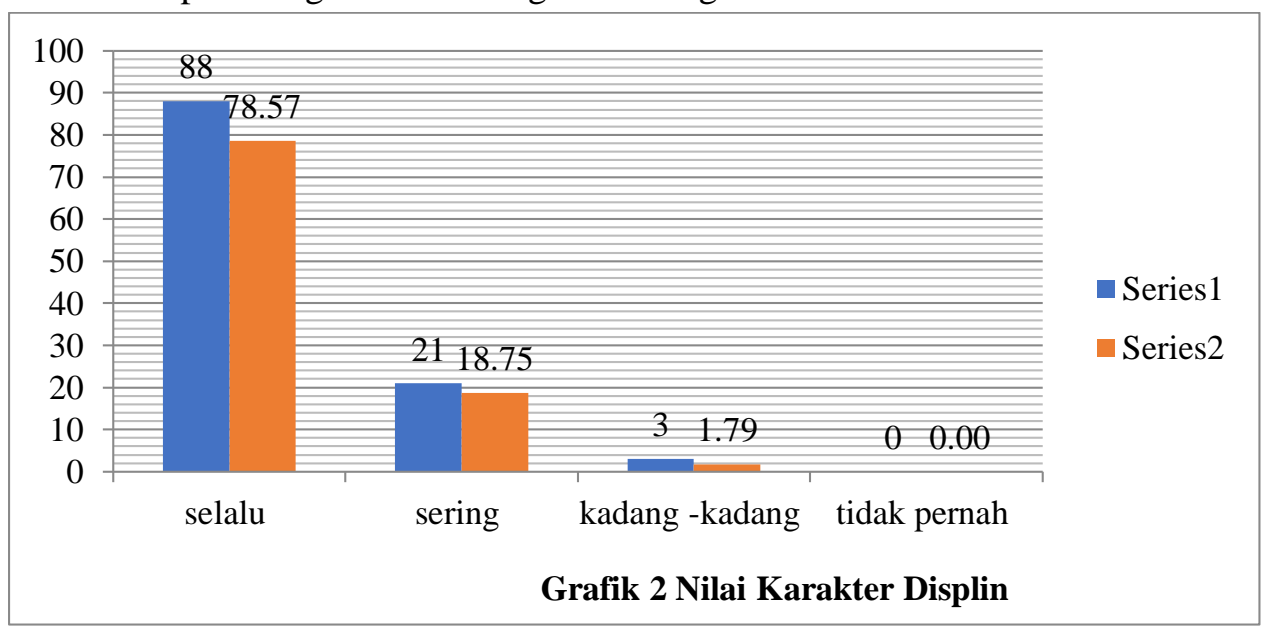

\section{Nilai Karakter Jujur}

Karakter yang sesuaiJujur merupakan mengakui, mengatakan ataupun membagikan sesuatu data yang sesuai dengan realitas dankebenaran (Herawan \& Sudarsana, 2017). Pada saat permainan Hadang berlangsung, karakter jujur yang ditunjukkan siswa berupa keterusterangan siswa pada kesalahan yang dilakukan, mengatakan sesuatu sesuai dengan fakta, dan tentu saja melakukan permainan dengan penuh kejujuran. Misalnya pada saat bermain Hadang, karakter jujur yang harus tetap dijaga siswa ketika siswa yang pertama tersentuh akan menjadi penjaga, siswa yang tidak jujur bisa saja mengaku tidak tersentuh karena takut atau tidak mau menjadi penjaga siswa yang jaga pada saat bermain Hadang berbohong telah menyentuh siswa lain yang sedang tidak jaga. Tetapi pada saat permainan berlangsung, sikap jujur ditunjukkan oleh kedua tim sehingga permainan berlangsung tanpa adanya kecurangan. Hasil persentase penerapan karakter jujur terlihat pada grafik berikut:

\section{Tabel 3. Nilai Karakter Jujur}

\begin{tabular}{lccccc}
\hline Jo. & Aspek Penilaian & Selalu & sering & kadang kadang & tidak pernah \\
\hline 1 & Siswa berkata jujur & 17 & 10 & 1 & 0 \\
\hline 2 & Siswa mengakui kesalahan & 18 & 7 & 3 & 0 \\
\hline & jumlah & 35 & 17 & 4 & 0 \\
\hline
\end{tabular}

Berdasarkan tabel 3. Mengenai nilai karakter Jujur maka dapat di jelaskan : skor 35 (62.50\%) dalam katagori selalu berkata jujur, skor $17(30.36 \%)$ dalam katagori sering berkata jujur, skor $4(7.14 \%)$ dalam katagori kadang-kadang berkata jujur, dan $0(0 \%)$ dalam katagori tidak pernah berkata jujur. Serta dapat di jelaskan juga hasil penelitian nilai katakter jujur dengan format diagram batang di bawah ini

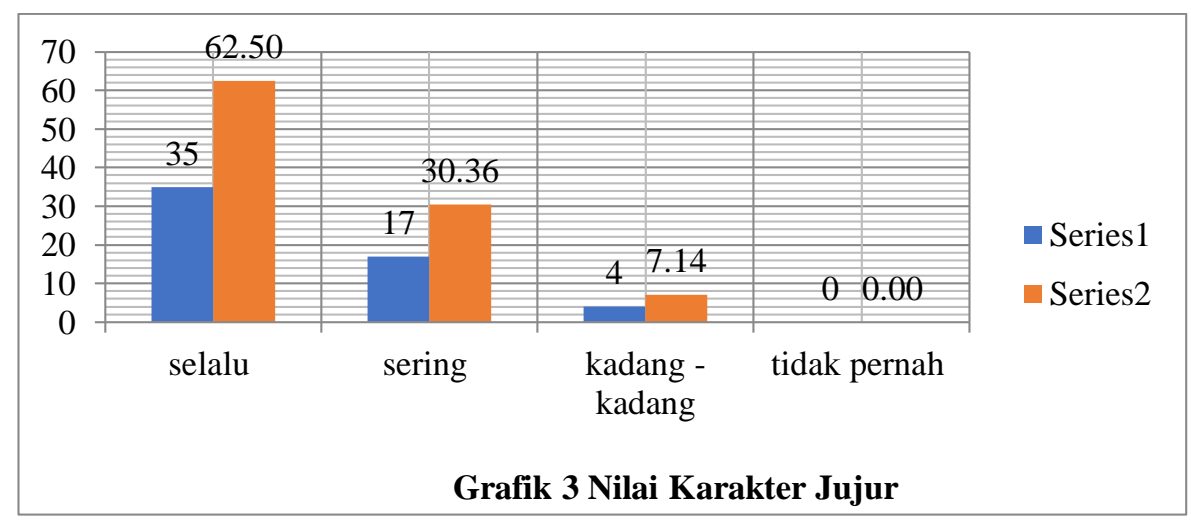


5348 Nilai-nilai Karakter pada Permainan Tradisional Hadang di Sekolah Dasar - Feby Elra Perdima, Muhammad Kristiawan

DOI: https://doi.org/10.31004/basicedu.v5i6.1640

\section{Nilai Karakter Kerja Keras}

Kerja keras merupakan berupaya dengan sepenuh batin dengan semantap daya buat berusaha memperoleh keingingan pendapatan hasil yang maksimum pada biasanya (Mirhan, 2016) serta menurut (Marzuki \& Hakim, 2019) bahwa aktivitasnya dilakukan untuk mewujudkan sesuatu keinginan/capaian, maka tumbuh rasa tanggung jawab yang besar. Hadang bersifat siswa untuk berlomba untuk mendapatkan poin sebanyak-banyaknya. Nilai karakter kerja keras siswa dalam permainan hadang dapat di lihat di tabel di bawah ini :

Tabel 4. Nilai Karakter Kerja Keras

\begin{tabular}{lccccc}
\hline Jo. & Aspek Penilaian & selalu & sering & kadang kadang & tidak pernah \\
\hline $\mathbf{1}$ & Siswa berusaha untuk menang & 24 & 3 & 0 & 0 \\
\hline $\mathbf{2}$ & bersunguh-sunguh & 26 & 1 & 1 & 0 \\
\hline $\mathbf{3}$ & percaya diri & 21 & 7 & 0 & 0 \\
\hline $\mathbf{4}$ & tidak mudah menyerah & 16 & 10 & 2 & 0 \\
\hline & jumlah & 87 & 21 & 3 & 0 \\
\hline
\end{tabular}

Berdasarkan tabel 4. Mengenai nilai karakter kerja keras maka dapat di jelaskan : Skor 87 (78.38\%) dalam katagori selalu kerja keras dalam bertanding, Skor 21 (18.92\%) dalam katagori sering kerja keras dalam bertanding, Skor $3(1.80 \%)$ dalam katagori kadang-kadang kerja keras dalam bertanding. Serta dapat di jelaskan juga hasil penelitian nilai katakter kerja keras dengan format diagram batang di bawah ini

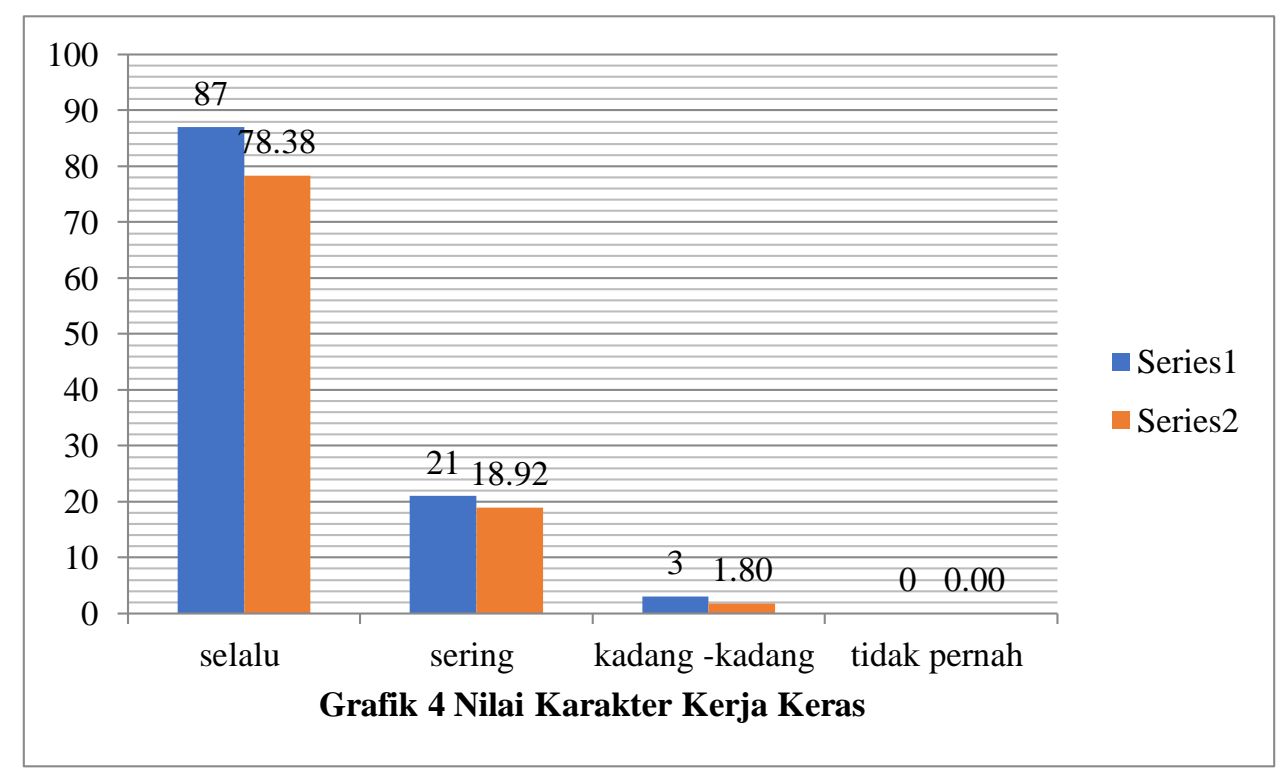

\section{Nilai Karakter Tangung Jawab}

Karakter tanggung jawab diperlihatkan siswa dari sikap mereka dalam menyelesaikan permainan. Setiap siswa berperan pada tugas masing-masing, baik sebagai penjaga maupun lawan. Tanggung jawab seorang ketua tim dan anggota terlihat dari sikap untuk memenangkan permainan. Hasil persentase penerapan karakter tangung jawab terlihat pada grafik berikut:

Tabel 5. Nilai Karakter Tangung Jawab

\begin{tabular}{cccccc}
\hline No. & Aspek Penilaian & Selalu & sering & kadang kadang & tidak pernah \\
\hline 1 & menjalankan tugas dengan baik & 15 & 8 & 5 & 0 \\
\hline 2 & nempertahankan tim untuk menang & 18 & 7 & 3 & 0 \\
\hline & jumlah & 33 & 15 & 8 & 8 \\
\hline
\end{tabular}


Berdasarkan tabel 5. Mengenai nilai karakter tangung jawab maka dapat di jelaskan : skor 33 (58.93\%) dalam katagori selalu bertanggung jawab dalam bertanding, skor 15 (26.79\%) dalam katagori sering bertanggung jawab dalam bertanding, skor 3 (14.29\%) dalam katagori kadang-kadang bertanggung jawab dalam bertanding, dan $0(0 \%)$ dalam katagori tidak pernah bertanggung jawab dalam bertanding. Serta dapat di jelaskan juga hasil penelitian nilai katakter tangung jawab dengan format diagram batang di bawah ini

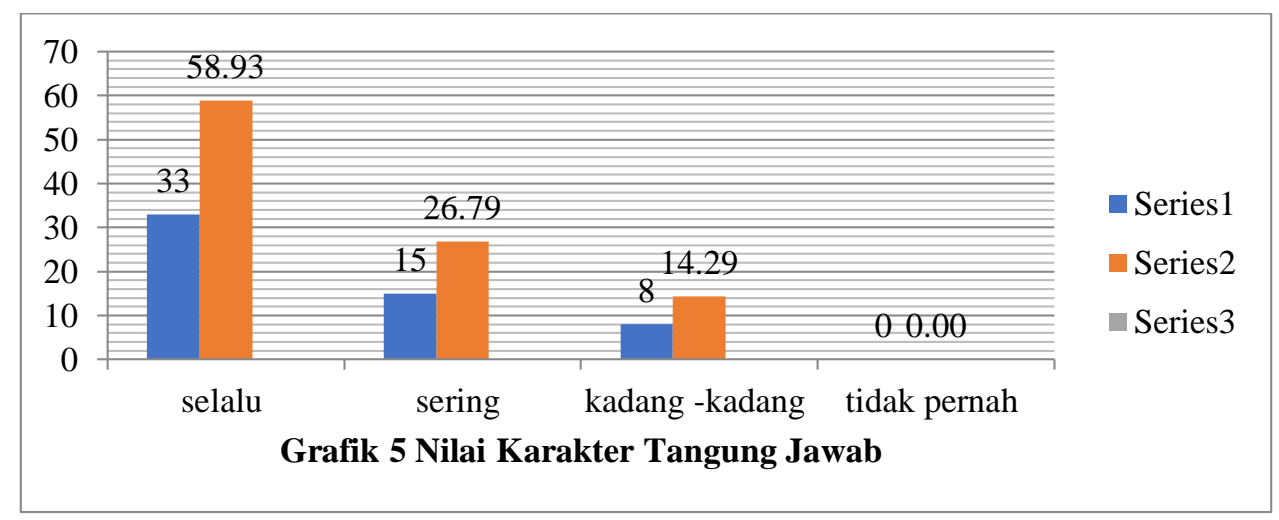

\section{PEMBAHASAN}

Pembentukan karakter melalui permainan tradisional dapat dilihat dengan adanya nilai- nilai karakter yang terkandung didalam permainan tradisional itu. Nilai- nilai itu hendak menjadi suatu nilai- nilai yang akan membentuk karater generasi muda yang berkarakter. Nilai- nilai yang terdapat didalam permainan tradisional antara lain kejujuran, ketegaran, kebersamaan, toleran, suka membantu, sportif, patuh serta mudah bersahabat (Huda \& Prasetyo, 2016). Pembentukan karakter generasi muda yang baik akan berdampak daerahnya serta bisa main permainan tradisional. Permainan tradisional harus kita lestarikan mengenang nilai- nilai yang tercantum didalamnya sangatah penting bagi pembentukan karakter generasi muda.

Analisa ini bersifat Informasi yang dicermati terperinci dalam lembar observasi yang sudah melampaui cara pengesahan dengan indikator-indikator penyesuaian dari nilai- nilai karakter yang dicoba ataupun ditunjukkan oleh siswa saat mereka melaksanakan olahraga permainan tradisional hadang. Sebaliknya, data tambahan yang tidak diperoleh pada saat observasi didapat lewat cara tanya jawab. Tanya jawab dicoba buat mengenali sebagian aspek yang membuat siswa kelihatan terbiasa memperlihatkan nilai- nilai karakter saat main Hadang. Tidak hanya itu, tanya jawab pula dipakai buat mengenali lebih jauh pada siswa alasan- alasan mereka karena tidak membuktikan nilai- nilai karakter pada saat bermain hadang.

Adapun tujuan dari penelitian ini untuk mengetahui nilai nilai karakter yang terkandung dalam permainan hadang. Penelitian ini diharapkan mampu membuat guru untuk mengidentifikasi nilai nilai apa saja yang terkandung dalam permainan tradisional hadang. Bersumber pada hasil riset sebagai berikut (1) Nilai Karakter Religius dapat di jelaskan: skor 60 (72.29\%) dalam katagori selalu memiliki nilai karakter religius saat bermain permainan tradisional hadang, skor 20 (24.10\%) dalam katagori sering memiliki nilai karakter religious saat bermain permainan tradisional hadang, skor 3 (3.61\%) dalam katagori kadang-kadang memiliki nilai karakter religious saat bermain permainan tradisional hadang, dan $0(0 \%)$ tidak ada memiliki nilai karakter religious saat bermain permainan tradisional hadang. 2) Nilai Karakter Displin maka dapat di jelaskan: skor 88 (78.575) dalam katagori selalu memiliki nilai karakter displin saat bermain permainan tradisional hadang, skor 21 (18.75) dalam katagori sering memiliki nilai karakter displin saat bermain permainan tradisional hadang, skor $3(1.79 \%)$ dalam katagori kadang-kadang memiliki nilai karakter displin saat bermain permainan tradisional hadang. 3) Nilai Karakter Jujur skor 35 (62.50\%) dalam katagori selalu berkarakter jujur dalam bermain Permainan tradisonal hadang, skor 17 (30.36\%) dalam katagori sering berkarakter jujur dalam bermain Permainan tradisonal hadang, skor 4 (7.14\%) dalam katagori kadang-kadang 
5350 Nilai-nilai Karakter pada Permainan Tradisional Hadang di Sekolah Dasar - Feby Elra Perdima, Muhammad Kristiawan

DOI: https://doi.org/10.31004/basicedu.v5i6.1640

berkarakter jujur dalam bermain Permainan tradisonal hadang, dan $0(0 \%)$. 4) Nilai karakter kerja keras maka dapat di jelaskan : Skor 87 (78.38\%) dalam katagori selalu berkerja keras dalam bermain permainan hadang, Skor 21 (18.92\%) dalam katagori sering berkerja keras dalam bermain permainan hadang, Skor 3 (1.80\%) dalam katagori kadang-kadang berkerja keras dalam bermain permainan hadang. 5) Nilai Karakter Tangung Jawab skor 33 (58.93\%) dalam katagori selalu bertanggung jawab dalam tim, skor 15 (26.79\%) dalam katagori sering bertanggung jawab dalam tim saat bermain permainan tradisonal hadang, skor 3 (14.29\%) dalam katagori kadang-kadang permainan tradisonal hadang, dan $0(0 \%)$ dalam katagori tidak pernah.

Hasil penelitian (Basyarudin \& Johaidah, 2018) menyimpulkan permainan tradisional yang dilakukan anak-anak tersebut, mengajarkan nilai-nilai karakter berupa cinta tanah air, demokratis, kepemimpinan, tangung jawab, sportif, dan jujur. Sementara penelitian lain juga menyimpulkan bahwa permainan tradisional harus dikembalikan posisinya sebagai permainan anak Indonesia dimana semua pihak dapat memperkenalkannya dan memainkannya bersama anak bahkan bisa mengupayakan memodernkan permainan anak tradisonal. Permainan tradisional digunakan sebagai alat untuk dapat memperkenalkan, mengajarkan, dan menerapkan nilai-nilai karakter(Nur, 2013). Penelitian yang dilakukan oleh (Susanto \& Ermawan, 2013) mengungkapkan hasil penelitiannya yang menunjukkan bahwa nilai-nilai karakter yang harus ada dalam pembelajaran penjas adalah disiplin, tekun, tanggung jawab, ketelitian, kerja sama, toleransi, percaya diri dan keberanian

\section{KESIMPULAN}

Ada lima nilai karakter yang terkandung dalam permainan tradisional hadang yang diterapkan pada siswa kelas VI 1 Sekolah Dasar 1 Muara Aman Kabupaten Lebong yaitu: religius, disiplin, jujur, kerja keras, dan tanggung jawab. Siswa yang menerapkan nilai-nilai karakter disebabkan adanya kesadaran diri sendiri sebab karakter-karakter yang mereka tunjukkan sudah sejak lama mereka ketahui dan terapkan. Selain itu, terdapat siswa yang tidak menerapkan beberapa nilai-nilai karakter dikarenakan ketidaksengajaan siswa ataupun karena ketidaktahuan dan perasaan kurang bisa mengendalikan diri untuk tetap menerapkan nilai-nilai karakter.

\section{DAFTAR PUSTAKA}

Ajat Rukajat. (2018). Pendekatan Penelitian Kualitatif. Deepublish.

Amirudin, Y. (2019). Pendidikan Karakter Berbasis Nilai-Nilai Aswaja. Vicratina: Jurnal Pendidikan Islam, 2(2), 109-120. Http://Riset.Unisma.Ac.Id/Index.Php/Fai/Article/View/4873

Andriani, T. (2012). Permainan Tradisional Dalam Membentuk Karakter Anak Usia Dini. Jurnal Sosial Budaya, 9(1), 121-136.

Atika, A. (2018). Pengaruh Disiplin Kerja Dan Etika Kerja Terhadap Komitmen Kerja Pegawai Pada Kantor Dewan Perwakilan Rakyat Daerah Kabupaten Langkat. Universitas Medan Area.

Basyarudin, A., \& Johaidah, M. (2018). Nilai-Nilai Karakter Dalam Olahraga Tradisional Aceh Di Gampong Paya Bujok Seuleumak Kota Langsa. Seuneubok Lada: Jurnal Ilmu-Ilmu Sejarah, Sosial, Budaya Dan Kependidikan, 5(2), 106-115. Https://Ejurnalunsam.Id/Index.Php/Jsnbl/Article/View/887

Ewan Irawan, Rabwansatriawan, \& Amar, K. (2021). Pengaruh Permainan Tradisional Tapa Gala Untuk Meningkatkan Imunitas Tubuh Siswa Sdn Sumi 1 Di Masa Pandemi Covid-19. Musamus Journal Of $\begin{array}{lllll}\text { Physical Education } & \text { And }\end{array}$ Http://Ejournal.Unmus.Ac.Id/Index.Php/Physical/Article/View/3545/1929 
5351 Nilai-nilai Karakter pada Permainan Tradisional Hadang di Sekolah Dasar - Feby Elra Perdima, Muhammad Kristiawan

DOI: https://doi.org/10.31004/basicedu.v5i6.1640

Hariandi, A., \& Irawan, Y. (2016). Peran Guru Dalam Penanaman Nilai Karakter Religius Di Lingkungan Sekolah Pada Siswa Sekolah Dasar. Jurnal Gentala Pendidikan Dasar, 1(1), 176-189. Https://Doi.Org/10.22437/Gentala.V1i1.7097

Herawan, K. D., \& Sudarsana, I. K. (2017). Relevansi Nilai Pendidikan Karakter Dalam Geguritan Suddhamala Untuk Meningkatkan Mutu Pendidikan Di Indonesia. Jurnal Penjaminan Mutu, 3(2), 223 236. Http://Www.Ejournal.Ihdn.Ac.Id/Index.Php/Jpm/Article/View/203

Huda, M. N., \& Prasetyo, E. (2016). Permainan Tradisional Sebagai Wahana Pembentukan Karakter Generasi Muda. Seminar Nasional: Pembentukan Karakter Dan Moralitas Bagi Generasi Muda Yang Berpedoman Pada Nilai-Nilai Pancasila Serta Kearifan Lokal.

Kementerian Olahraga. (2005). Undang-Undang Republik Indonesia.

Khotimah, K. (2016). Model Manajemen Pendidikan Karakter Religius Di Sdit Qurrota A'yun Ponorogo. Muslim Heritage, 1(2), 371-388. Https://Doi.Org/10.21154/Muslimheritage.V1i2.605

Marzuki, I., \& Hakim, L. (2019). Strategi Pembelajaran Karakter Kerja Keras. Rausyan Fikr: Jurnal Pemikiran Dan Pencerahan, 15(1), 79-87. Https://Doi.Org/10.31000/Rf.V15i1.1370

Maulana, D. A., \& Riyadi, S. (2021). Nilai-Nilai Keolahraga An Dalam Permainan Tradisional "Main Jaran " Pada Masyarakat Sumbawa Sports Values In The Traditional Game Of " Main Jaran "In The People Of Sumbawa. Prosiding Seminar Nasional Pendidikan Kepelatihan Olahraga, 1(1), 1-12.

Mirhan, J. (2016). Hubungan Antara Percaya Diri Dan Kerja Keras Dalam Olahraga Dan Keterampilan Hidup. Jurnal Olahraga Prestasi, 12(1), 115487. Https://Doi.Org/10.21831/Jorpres.V12i1.9499

Nanda, Y., \& Sugito, H. (2015). Membentuk Gerak Dasar Pada Siswa Sekolah Dasar Melalui Permainan Tradisional. 1(1).

Nur, H. (2013). Membangun Karakter Anak Melalui Permainan Anak Tradisional. Jurnal Pendidikan Karakter, O(1). Https://Journal.Uny.Ac.Id/Index.Php/Jpka/Article/View/1290

Safari, I., \& Safari, I. (2010). Analisis Unsur Fisik Dominan Pada Olahraga Tradisional. Jurnal Kependidikan: Penelitian Inovasi Pembelajaran, 40(2), 132617. Https://Doi.Org/10.21831/Jk.V40i2.495

Siyoto, S., \& Sodik, M. A. (2015). Dasar Metodologi Penelitian -. Literasi Media Publish.

Sobri, M., Nursaptini, N., Widodo, A., \& Sutisna, D. (2019). Pembentukan Karakter Disiplin Siswa Melalui Kultur Sekolah. Harmoni Sosial: Jurnal Pendidikan Ips, 6(1), 61-71. Https://Journal.Uny.Ac.Id/Index.Php/Hsjpi/Article/View/26912

Sonjaya, A. R., Arifin, Z., \& Pratiwi, R. A. (2021). Revitalisasi Permainan Tradisional Sebagai Wahana Peredam Permainan Digital Pada Anak. Jurnal Pendidikan Uniga, 15(1), 385. Https://Doi.Org/10.52434/Jp.V15i1.1173

Susanto, \& Ermawan. (2013). Pembelajaran Pendidikan Jasmani Berbasis Karakter Untuk Meningkatan NilaiNilai Afektif Di Sekolah Dasar. Jurnal Pendidikan Karakter, 1(3). Https://Doi.Org/10.21831/Jpk.V0i3.2751 